Ann. Biol. anim. Bioch. Biophys., I967, 7 (3), 33I-342.

\title{
EFFECTS OF TEMPERATURE AND LIGHT ON MOVEMENT CHARACTERISTICS AND LONGEVITY OF COCK SPERMATOZOA (')
}

\author{
C. VAN DUIJN, Jr \\ Biophysics Department, \\ Research Institute for Animal Husbandry, \\ a Schoonoord „, Zeist (The Netherlands)
}

\section{SOMMAIRE}

Dans ce mémoire sont étudiés les effets de la température sur la vitesse de déplacement initiale moyenne du spermatozoìde de Coq, ainsi que les taux de décroissance de cette vitesse et du nombre de spermatozoìdes mobiles, soit à l'obscurité, soit sous un éclairement constant. Le dilueur utilisé était une modification du dilueur standard citrate-jaune d'œuf, clarifié.

$\mathrm{La}$ vitesse et le nombre de spermatozoìdes mobiles ont été déterminés grâce à la méthode photoélectrique de RIKMENSPOEL réajustée pour les spermatozoïdes de Coqs.

$\mathrm{La}$ vitesse initiale moyenne croît non linéairement de 2 à $45^{\circ} \mathrm{C}$ et chute très brutalement audessus de $55^{\circ} \mathrm{C}$.

Dans la gamme de $\circ$ à $45^{\circ} \mathrm{C}$ les constantes de diminution de la vitesse de déplacement avec le temps $\partial \bar{v} / \partial t$, du nombre de spermatozoïdes mobiles $k_{\mathrm{N}}$, du produit $\mathrm{N} v$, suivent l'équation d'Arrhenius relative à la dépendance des réactions chimiques vis-à-vis de la température. Ceci implique qu'il existe une relation linéaire entre $: \log \partial \bar{v} / \partial t, \log k_{\mathrm{N}}$ et $\log k_{\mathrm{N}} \bar{v}$ d'une part et I/T d'autre part ( $\mathrm{T}=$ température absolue).

L'énergie apparente de l'activation des processus de dégradation cellulaire s'élève à $\mathbf{I}$ 088 \pm I $620 \mathrm{cal} / \mathrm{mol}$. pour les échantillons maintenus à l'obscurité et à I $2200 \pm 2500 \mathrm{cal} / \mathrm{mol}$. sous éclairement de $983 \pm 3$ lux.

La photosensibilité du sperme de Coq est inférieure à celle des spermatozoïdes de Taureau. Comme chez le Taureau, elle est étroitement liée à la température et suit aussi une équation d'Arrhenius (corrélation $\log$ (photosensibilité) et $\mathrm{I} / \mathrm{T}: r=-0,98 \mathrm{P}<0,00 \mathrm{I}$ ).

Cette relation s'explique en admettant que l'éclairement est assimilable à un processus agissant sur des cibles multiples.

L'énergie d'activation apparente du processus photochimique est de $-2354 \mathrm{cal} / \mathrm{mol}$. pour le spermatozoïde de Coq, valeur inférieure à celle trouvée chez le Taureau antérieurement $\left(-895^{8} \mathrm{cal} /\right.$ mol.).

Les valeurs du $Q_{10}$ pour le spermatozoïde de Coq varient de 0,84 à 0,87 , pour une gamme de température de o à $40^{\circ} \mathrm{C}$, montrant que la relation avec la température est due principalement av processus photochimique lui-même et non à un effet thermique secondaire.

(1) The I98th publication tof he Research Institute for Animal Husbandry « Schoonoord * at Zeist, The Netherlands. 


\section{INTRODUCTION}

Data on the effect of temperature on the mean swimming velocity and longevity of bull spermatozoa, determined by objective physical methods with photoelectric equipment, have been published by RIKMENSPOEI, (I957 $b$, I962), VAN DuIJN (I963) and VAN DUIJN and VAN LIFROP (Ig66). The latter two authors could demonstrate a definite dependence of photo-sensitivity of bull spermatozoa on temperature. In the present study the same methods of investigation have been applied to cock spermatozoa and will be shown to be in general agreement with the results relating to bovine specimens.

\section{MATERIAL AND METHODS}

The material included 14 ejaculates from 5 Corney Rock type cocks, all of the same strain, 9 months of age and raised and kept under identical conditions. Semen was collected in prewarmed clean glass tubes (to prevent cold shock) by manual stimulation and then stored in a Dewar vessel with ice (protected from direct contact by an air mantle), allowing slow and gradual cooling down to $1.9 \pm 1.2$ (S. D.) ${ }^{\circ} \mathrm{C}$ during transport to the laboratory. About one hour after collection the samples were diluted $I:$ roo in two steps of $I:$ IO. the second step immediately following the first one. The diluent was a modified ultramicroscopically clear egg-yolk - sodium citrate buffer medium, containing 15 per cent egg-yolk, $\mathrm{pH} 6.57 \pm 0.03$ (absolute error) measured at $22-23^{\circ} \mathrm{C}$ (temperature coefficient $0,003 \mathrm{pH}$ unit per $\left.{ }^{\circ} \mathrm{C}\right)$, freezing point depression $\Delta=-0.660$, density $d_{20 / 20}=\mathrm{I} .025$,

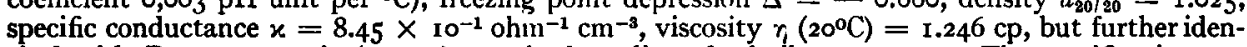
tical with RIKMENSPOEL's (1957 $a$ ) standard medium for bull spermatozoa. The specifications as mentioned here were found to be u ieful for cock spermatozoa in this type of medium, but the medium as a whole proved inferior to skim milk (used as the standard diluent in fowl A. I. in the Netherlands) with respect to fertilization results. ielding only about 60 per cent of the number of fertilized eggs obtained with skim milk under identical insemination conditions. Since our photoelectric method requires an optically clear medium, we had to accept this less favourable condition.

For studying the immediate effect of temperature on the initial velocity of cock spermatozoa, drops of diluted semen stored at $2^{\circ} \mathrm{C}$ were warmed up to different temperatures and recordings taken at the same temperature in the apparatus.

For investigating the effects of storage temperature and light on the potential movement characteristics and longevity, sub-samples of each ejaculate were incubated in glass tubes, placed in water baths kept at different temperatures, ranging from $2-45^{\circ} \mathrm{C}$. At each temperature one further sub-sample was placed in a plain clear glass tube and subjected to a constant illumination of 983 \pm 3 lux, using a battery of incandescent bulbs (220 V, $150 \mathrm{~W})$ with internal mirrors, as the light sources.

The dark controls were kept in small glass tubes of the same size, but made of brown glass, painted black, wrapped in aluminium foil and pressed into a white tube of soft plastic to avoid rise of temperature due to the heating effect of the light. These tubes were placed in the same water baths and all tubes in all baths were gently agitated at the same rate (driven from the same shaft) to prevent sedimentation of the spermatozoa. A cooling tank, operated with running water, was placed between the water baths and the battery of lamps. The entire equipment was installed in a thermostatically-controlled room kept at $5^{\circ} \mathrm{C}$.

Drops of the diluted semen samples were taken at regular intervals of time, brought into a microchamber and warmed for 5 minutes to $42^{\circ} \mathrm{C}$. The samples were then brought under the microscope, kept at this same temperature, and the recordings made. Details of the photo-electric measuring procedure have been described in previous publications (RIKMENSPOEL, $1957 b$, 1960, 1962 ; VAN DUIJN and RIKMENSPOEL, I960; VAN DUIJN, 1962). The measuring nomogram devised for bull sperm had to be exchanged for another one, calibrated for cock spermatozoa. It was found, however, that VAN DUIJN's nomogram for bull sperm could be used if a correction factor of $\times 1.425$ was applied to the velocity values read. 
From the recordings the mean velocities were calculated with correction for velocity decrease during measurement as well as for the dependence of the probability of observing any specimen on its speed (VAN DUIJN, I963). The main effect of this correction is a change in the shape of the velocity frequency distributions, not to be discussed here, but with respect to the mean velocities there is a strictly linear correlation between the mean velocities $\bar{v}$, calculated after RIKMENSPOEL's original system, and those with correction for deterioration effects during measurement (designated by $\left.\bar{v}^{*}\right): r=0.9996$, with 3990 degrees of freedom. Consequently, it does not matter which system is followed in the course of comparative investigations where only the mean velocity and velocity decrease with time, but not the velocity frequency distributions, are of interest. The difference between $\bar{v}$ and $v^{*}$ consists only in a systematic difference in the numerical values $\left(\bar{v}^{*}>\bar{v}\right)$.

The rate constants of deterioration on storage under the different conditions were obtained from the successive measurements taken at regular intervals of time.

\section{RESUI,TS}

\section{Initial mean velocities of normally moving specimens as a function of temperature}

Text-figure I gives the general relationship between the initial mean velocities as a function of temperature, determined during a recording time of 4 minutes following after a warming up period of 5 minutes to reach the required temperature for the observation. At the extremes the numbers of moving specimens and their velocities were too small for photo-electric measurement; therefore direct visual observation was employed for estimating the end-points. The first visual observation of specimens displaying forward movement was obtained at $8{ }^{\circ} \mathrm{C}$, corresponding to a mean

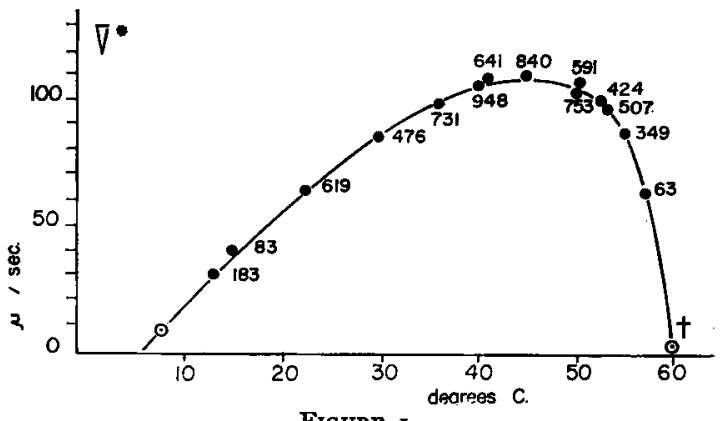

Relationship between the initial mean velocity of cock spermatozoa $\overline{\mathrm{v}}^{*}$ and temperature, determined after a warming up period of 5 minutes to reach each measuring temperature, all having started at the same storage temperature of about $2^{\circ} \mathrm{C}$ (see text). Pooled data of 5 ejaculates from 5 different Corney White type cocks, each measured three times. The figures near the points indicate the total numbers of spermatozoa measured.

Relation entre la motilité initiale moyenne du spermatozoide de coq $\overline{\mathrm{v}}^{*}$ et la température. Détermination après un réchauffement de 5 minutes d la température étudiée, la température de départ étant toujours la méme, environ $2^{\circ} \mathrm{C}$ (voir le texte). Moyenne oblenue avec le mélange de 5 éjaculats de 5 coqs Corney White; chaque mesure étant répétée trois fois. Nombre tolal de spermatozoïdes étudiés : 7208.

velocity (of these moving specimens only) of 6 microns/second as read from the extrapolation of the $\bar{v}^{*}=\mathscr{F}(\mathrm{T})$ curve. From the total curve the absolute lower limit is estimated at $6^{\circ} \mathrm{C}$, which compares quite well with the visual observations. In the temperature region between $I 5$ and $40^{\circ} \mathrm{C}$ the mean velocity increases at a nearly constant rate with increasing temperature. At about $45^{\circ} \mathrm{C}$ the curve reaches a top, decreasing slowly at first, but falling down very rapidly above $55^{\circ} \mathrm{C}$. No moving specimen was ever encountered after 5 minutes at $60^{\circ} \mathrm{C}$. 
The absolute maximum temperature at which a sufficient number of specimens survived at least 8 minutes differed somewhat between different ejaculates. The figures given should therefore be taken as estimates of the order of magnitude rather than as absolute values.

\section{Effects of storage temperature in darkness}

If it is assumed that natural ageing of spermatozoa, starting with a decrease of potential motility under standard conditions and finally leading to death of any individual cell, depends on one or more chemical reactions taking place inside the cell that are not completely reversible, the relationship between the rate constants of the deterioration process and temperature may be expected to fit the Arrhenius equation for temperature-dependence of the rate constants of chemical reactions :

$$
k=\mathrm{A} \cdot \exp \left[-\mathrm{E}_{\mathbf{A}} / \mathrm{R}^{\prime} \mathrm{T}\right]
$$

Or written in the logarithmic form :

$$
\ln k=-\frac{\mathrm{E}_{\mathrm{A}}}{\mathrm{RT}}+\ln \mathrm{A}
$$

where $\mathrm{A}=\mathrm{a}$ constant representing the probability that a reaction occurs, $\mathrm{E}_{\mathbf{A}}=$ the apparent energy of activation, $R=$ the gas constant $(1.987 \mathrm{cal} / \mathrm{mole}$ degree), $\mathbf{T}=$ absolute temperature $\left({ }^{\circ} \mathrm{K}\right)$.

The rate constants in the case of deteriorating populations of spermatozoa are the rate of decrease of potential velocity with time $(-\partial \bar{v} / \partial t)$ and the rate constants $k$ of the decrease in numbers $\mathrm{N}$ of normally moving spermatozoa $\left(k_{\mathrm{N}}=d(\ln \mathrm{N}) / d t\right)$ and of migration rates, the latter being defined as the product of $\mathrm{N}$ with the mean velocity $\bar{v}$ (hence $k_{\mathrm{N} \bar{v}}=d(\ln \mathrm{N} \bar{v} / d t)$.

Over periods exceeding those of the present experiments both $\mathrm{N}$ and $\mathrm{N} \bar{v}$ decrease exponentially with time, just the same as shown in many previous investigations with bovine spermatozoa (RIKMENSPOEL I957 $b$, I960, I962; VAN DUIJN, I96I, I962, I963 ; VAN DUIJN and RIKMENSPOEL, I960) :

$$
y(t)=y_{0} \cdot \mathrm{e}^{-k t}
$$

where $y=\mathrm{N}$ or $\mathrm{N} \bar{v}$, respectively, $y_{0}=$ initial value of $y, y(t)=$ functional value of $y$ at time $t, k=$ rate constant.

Linear relationships must then exist between $\log \mathrm{N}$ and $\log \mathrm{N} v$, and also between $\log k_{\mathrm{N}}$ and $\log k_{\mathrm{N}} \bar{v}$. In the investigations previously quoted these relationships have been demonstrated most convincingly for bull spermatozoa, with Corr. $\log \mathrm{N} \mathrm{X} \log$ $N \bar{v}: r=0.93$, with 620 degrees of freedom. Linear relationships have also been demonstrated experimentally between $\log (-\partial v / \partial t)$ and $\log k_{\mathrm{N}}$ and $\log k_{\mathrm{N} v}$, respectively, with Corr. $\log (-\partial \bar{v} / \partial t) \times \log k_{\mathrm{N}}: r=0.85$, with $\mathrm{r} 7 \mathrm{o}$ degrees of freedom, and Corr. $\log (-\partial \bar{v} / \partial t) \times \log k_{\mathrm{v} \bar{v}}: r=0,87$, with $\mathrm{I} 83$ degrees of freedom. None of the aforementioned $r$ values differed significantly from $r=\mathrm{I}$. Hence these linear relationships may be accepted as being functional.

From these relationships it follows that the three rate constants are essentally equivalent (VAN DUIJN, I963) and this has been confirmed in our work with cock spermatozoa. 
Text-figure 2 gives the relationship between velocity decrease with time $-\partial \bar{v} / \partial t$ and storage temperature, all velocity measurements having been taken at $42^{\circ} \mathrm{C}$. The conformity to the supposed Arrhenius type of equation can be checked by its transformation to a straight line, by plotting $\log (-\partial \bar{v} / \partial t), \log k_{\mathrm{N}}$ or $\log k_{\mathrm{N}} \bar{v}$ as a function of the reciprocal of the absolute temperature, as follows from equation ( $r a$ ). These transformations are given here for $-\partial \bar{v} / \partial t$ and $k_{N}$, respectively, in Text-figures 3 and 4 . There is good agreement over the temperature range from $+o$ up to approximately $45^{\circ} \mathrm{C}$, no statistical difference from linearity being demonstrable. At still higher temperatures it would not be reasonable to expect the same type of relationship to hold, because then the physiological temperature region is surpassed and the rates of deterioration must increase more rapidly, owing to such processes as heat inactivation and denaturation of enzymes and other protein systems.

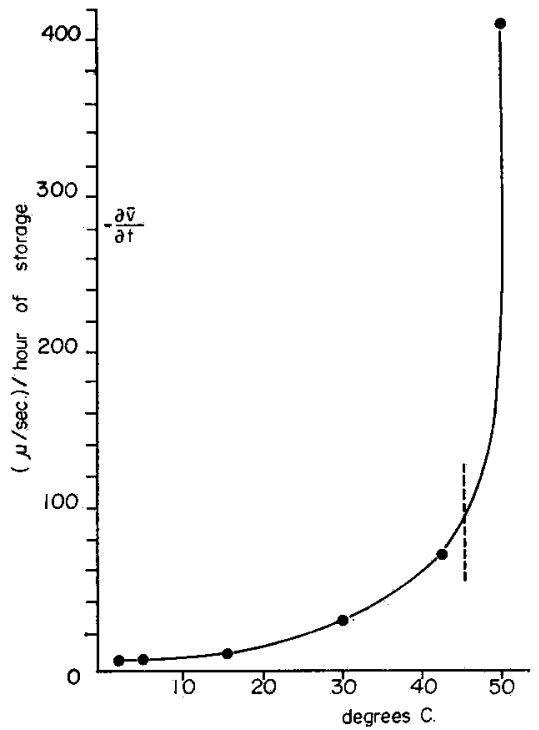

Figure 2

Relationship between the rate of velocity decrease with time $-\partial \overrightarrow{\mathrm{v}} / \partial \mathrm{t}$ and storage temperature. In the temperature range to the left of the vertical dotted line the relationship follows the Arrhenius equation. Compare Text-Fig. 3. Typical example of the results obtained in one of the experiments.

Relation entre la perte de motilité en fonction du temps - ov/at et la température de conservation. Pour la gamme de températures située d gauche de la ligne pointillée, la relation suit l'équation d'Arrhenius. Voir la figure 3 , exemple-type des résultats obtenus dans une des expériences.

From the slopes of the linear parts of the plots the apparent energies of activation of the normal ageing process can be derived, since the slope is given by :

$$
\frac{d \ln k}{d \mathrm{~T}}=\frac{\mathrm{E}_{\mathrm{A}}}{\mathrm{R}^{\prime} \mathrm{T}^{2}}
$$

from which it follows that.

$$
\mathrm{E}_{\mathrm{A}}=\frac{4 \cdot 575 \cdot \mathrm{T}_{1} \cdot \mathrm{T}_{2}}{\mathrm{~T}_{2}-\mathrm{T}_{1}} \cdot{ }^{10} \log \frac{k_{2}}{k_{1}}
$$

For the samples kept in da:kness the overall result was $E_{A}=I 7088 \pm I 620$ cal/ mole. 


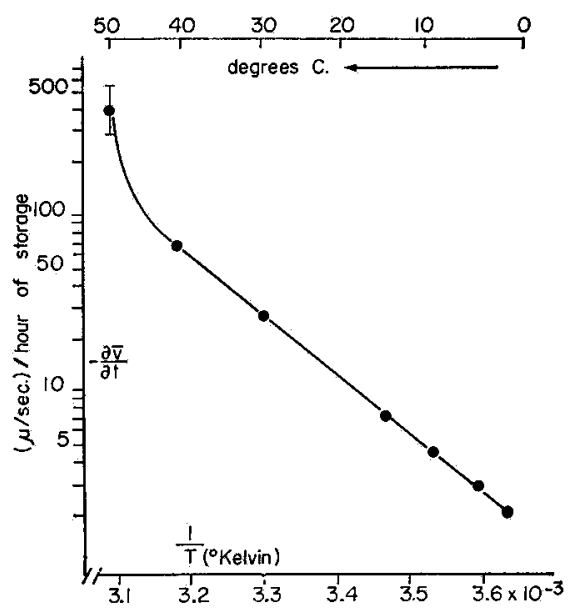

Figure 3

Arrhenius plot of the rate of decrease of the mean velocity in microns per second, per hour of storage at different temperature in darkness. Same data as shown in Texi-Fig. 2, illustrating the applicability of the Arrhenius type of equation over the range from +0 to $45^{\circ} \mathrm{C}$. Ordinate logarithmic.

Courbe d'Arrhenius exprimant le taux de diminution de la motilité moyenne en $\mu / \mathrm{sec} / \mathrm{h}$ de conservation differentes températures (obscurité). Mêmes données que dans la figure 2, montrant que l'équation d'Arrhenius s'applique dans une gamme de températures de +0 a $45^{\circ} \mathrm{C}$.

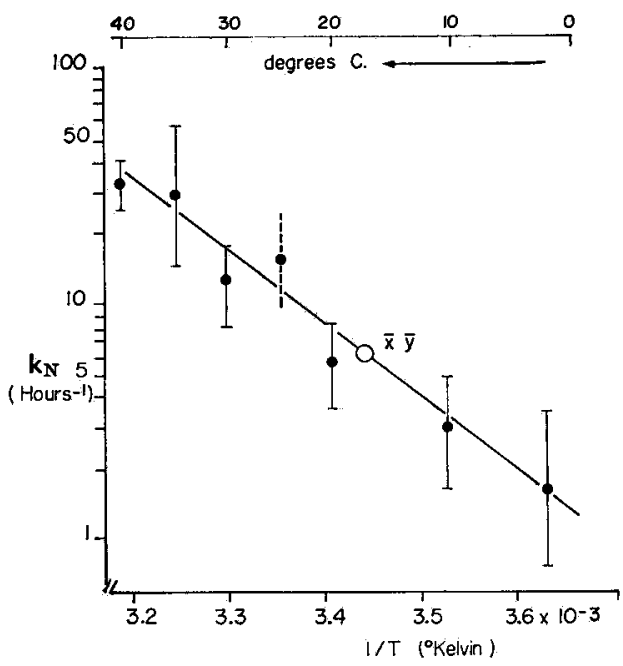

Figure 4

Arrhenius plot of temperature-dependence of the rate constant $k \mathrm{~N}$ of decrease of numbers of cock spermatozoa capable to normal movement under siandard conditions. Averaged data over all measurements, including 14 ejaculates from 5 different Corney White type cocks. Ordinate logarithmic. Storage in darkness.

Courbe d'Arrhenius montrant l'infuence de la température sur la constante $k_{\mathrm{N}}$ de diminution du nombre de spermatozoides de coq, capables d'un mouvement normal dans des conditions standard. Moyennes des résultats obtenus avec 14 ejaculats de 5 coqs Corney White (obscurité). 


\section{Effects of light at varying temperature}

At all temperatures included in the experiments longevity of the spermatozoa was significantly lower under illumination than in darkness.

For the samples kept under constant illumination at $983 \pm 3$ lux the energy of activation was $\mathrm{E}_{\mathrm{A}}=122 \mathrm{IO} \pm 2500 \mathrm{cal}$ mole. This lower figure as compared to that of the control samples stored in darkness demonstrates the accelerating effect of light on the rate of deterioration of cock spermatozoa.

Photo-sensitivity can be defined quantitatively by the factor with which the rate of deterioration is increased by a constant level of illumination, I, meaning that it is measured by :

$$
\mathrm{Y}_{\mathrm{I}}=\frac{(k y) \mathrm{I}}{(k y) \mathrm{I}=0}
$$

where $\mathrm{Y}_{\mathrm{I}}=$ relative photo-sensitivity (relative, because its numerical value will depend on the standard value chosen for I), and $k y$ represents either - $d v / \partial t, k_{\mathrm{N}}$ or $k_{\mathrm{N}} \bar{v}$ (VAN DUIJN, I963, VAN DUIJN and VAN LIEROP, I966).

The value of $Y_{I}$ is dimensionless and independent of which of these parameters is chosen. Therefore, the individual values can be averaged to combine the total result into one single relationship, which has the obvious advantage that fewer series of experiments are required for obtaining highly reliable results.

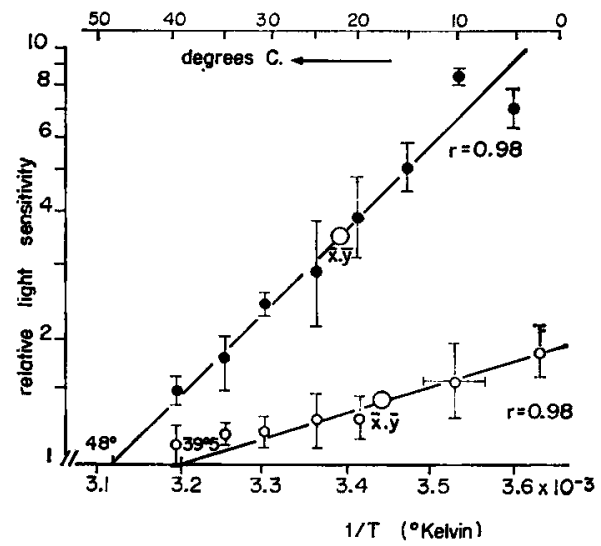

FIGURE 5

Arrhenius plot of temperature-dependence of photosensitivity of spermatozoa

(constant level of illumination of $983^{ \pm} 3$ lux)

- : bull spermatozoa (after data by VAN DUIJN and VAN LIEROP, 1966)

0 : cock spermatozoa

Courbe d'Arrhenius. Photosensibilité des spermatozoídes en fonction de la température

(niveau d'éclairement constant de $983_{3}^{ \pm} 3$ lux)

- : spermatozoîde de taureau

0 : spermatozoìde de coq

Photo-sensitivity of cock spermatozoa definitely decreases with increasing temperature, as shown by Text-figure 5. This figure is the linearized graph according to the Arrhenius type of relationship and for comparison the same function is shown for bull spermatozoa after previous investigations by VAN DUIJN and VAN LIEROP (rg66). The linear correlation coefficients for Corr. $\left(\log \mathrm{Y}_{\mathrm{I}}\right) \mathrm{X}(\mathrm{I} / \mathrm{T})$ are 0.98 for both 
C. VAN DUIJN, Jr

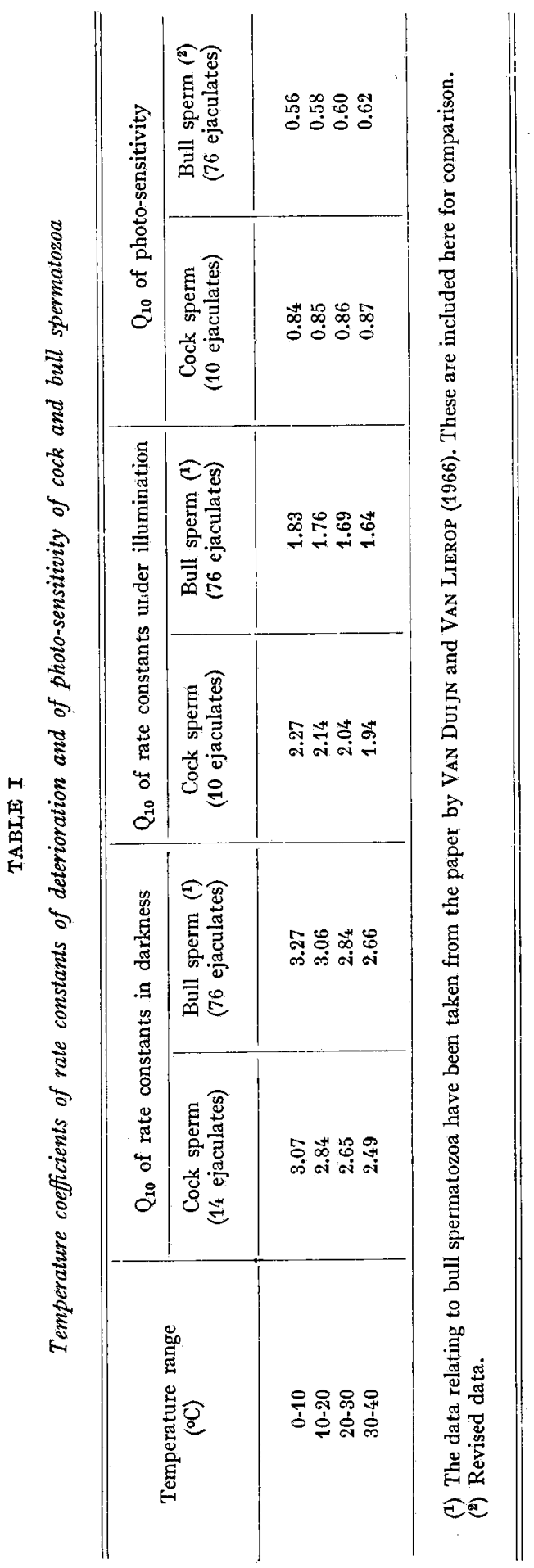


species, with $\mathrm{P}<1 \mathrm{IO}^{-5}$ for the bovine material, and $\mathrm{P}<\mathrm{IO}^{-3}$ for the cock. Photosensitivity of cock spermatozoa is obviously less than that of bull spermatozoa and the same holds true for the influence of temperature on the effect of illumination.

Since these $r$ values do not differ significantly from $r=\mathrm{I}$, here, too, the linear relationships may be accepted as being functional.

The apparent energies of activation of the photochemical process found were $-2534 \mathrm{cal} / \mathrm{mole}$ for cock sperm as compared to $-895^{8} \mathrm{cal} / \mathrm{mole}$ for bull spermatozoa ${ }^{(1)}$. The negative sign of the energy of activation indicates the activating or catalytic action of the light itself, actually meaning that the total energy of activation required for the deterioration process from other sources is diminished.

The apparent temperature coefficients $Q_{10}$ for different regions of the temperature range are shown in table $I$.

The very low $Q_{10}$ values of photo-sensitivity are a clear indication that its dependence on temperature is mainly due to the photochemical process itself and not to secondary thermal reactions, in which case a $Q_{10}$ value of the order of 2 or more would be expected, and anyhow never could become less than $I$.

\section{DISCUSSION}

The results of the present investigations on the general effect of temperature and light on cock spermatozoa are in complete agreement with those obtained previously with bull sperm (VAN DUIJN and VAN LIEROP, I966). The observations of dir ct harmful effects of illumination on cock spermatozoa by NORMAN and GoLDBERG (Ig6I) and NORMAN, GOLDBERG and PORTERFEID (I962) are confirmed, but there is complete disagreement with their statement that photo-sensitivity should be independent of temperature. There are several reasons for their apparent failure to detect this dependence. One of these may be the larger experimental errors occurring in the visual observation method used by them, as compared to our physical measurements, but this does not seem to be the most important factor.

The level of illumination used by NORMan, GoldDERg and PORTERFIELD was greatly in excess of that of ours, being approximately 9 I 500 lux $(8500 \mathrm{ft} \mathrm{cd})$ as compared to only 983 lux in our investigations. At the latter illumination level the effects of light and temperature alone were in the same order of magnitude, which is a condition rendering a measuring system maximally effective for detection of the separate components, whereas at a hundred times higher level of illumination the sensitivity of the system for detecting any effect of temperature is a same factor lower, too, and this combined with the lower overall accuracy of the visual measuring method could be sufficient explanation for this failure. These conditions are further aggravated by a less suitable choice of the parameters to characterize the effects.

(1) This value differs from that given in the original paper by VAN DUIJN and VAN LIEROP (1966), which has just appeared to suffer from a numerical error in the calculation. The $Q_{10}$ values of photo-sensitivity of bull spermatozoa have been recalculated accordingly and are given in the last row of table $I$ of the present paper. 
Norman et al. ( 1962 ) chose the period of time after the beginning of their observations at which movements stopped as a parameter for the process of deterioration. This has the important drawback that this moment can only be determined with reasonable accuracy in cases where life-spans are short enough to allow close and continuous observation of the process of deterioration (VAN DUIJN, I963; VAN DUIJN and VAN LIEROP, I966). Even then, there is a large statistical error, since one or two spermatozoa that have a markedly longer life-span can influence the result considerably. Furthermore, the ratio of periods of time having passed by till the last visible specimen has stopped movement, is not a linear and not even a direct measure of a biological effect if there is more than one variable, because in this parametric system it is impossible to correlate the results with proper controls. At any condition (so at any different temperature) there is a different rate of natural deterioration and a true measure of an effect can only be obtained by comparing the rates of deterioration under the standard darkness condition, and - in this case under illumination at the same temperature, as defined in equation (3).

NORMAN et al. (1962) truly demonstrated a darkness effect, meaning that after stopping illumination, the rate of deterioration still remains higher than in the samples continually kept in darkness. Now from this observed darkness effect alone it must be concluded from photochemistry that the illumination effect must depend on temperature, because a darkness effect can only occur in case of multiple-target or one-target - multiple-hit processes, so they could have detected the discrepancy by sufficiently sophisticated analysis of their own data. The shapes of the relationships between numbers of surviving (moving) specimens and time under constant very high level illumination analysed from our own data and from those contained in the paper by NoRMan et al. (Ig62) point to a multiple-target process rather than to a one-target - multiple-hit process, as follows from the sigmoidal course obtained under such conditions. From Norman et al.'s (rg62) material on bull spermatozoa I could calculate the probable number of targets as 6 , under their experimental conditions.

After the preceding argument it also follows from photochemistry and target theory that at certain levels of illumination deviations from Bunsen and Roscoe's reciprocity law must occur (Schwarzschild effect) and an intermittency effect can also be expected (MEES, I954). For bovine spermatozoa the Schwarzschild effect has already been demonstrated in specific experiments (VAN DUIJN and VAN LIEROP), data being prepared for separate publication.

Cock spermatozoa showed both less sensitive to the effect of light and of temperature, alone and in combination, than bull spermatozoa. It might be tempting to look for the reason of this difference in the different ultrastructural fibril patterns of the midpieces and tails, which in cock spermatozoa are of the simple $2+9$ type (LAKE, personal communications I965, I966) and in the bull, like all mammals, of the $2+9+9$ type, with the outer row of nine much stronger than the inner ring of doublet fibrils (FAWCETT, I962). However, this would require quite a lot of further comparative studies with spermatozoa of different species.

With respect to the practice of artificial insemination it is concluded that storing the semen at low temperature prior to insemination is as important for longevity in cock sperm as it is in bull. Results indicate that cock spermatozoa are less 
susceptible to cold shock than bull and boar sperm and survive at low temperatures for longer periods in undiluted semen, than the latter two mammalian species. The actual effect of storage temperature on fertilization results is being investigated in a series of A. I. experiments.

Reçu pour publication en juin 1967.

\section{ACKNOWLEDGMENTS}

The author is very much indebted to Dr. E. J. Van WeERDEN and Mr. J. B. Schutre at the Institute for Agricultural Research of Biochemical Products (ILOB), Wageningen, for the generous supply of cock semen and kind cooperation during the course of these investigations and to his own assistent Mr. C. VAN VOORST for his enthusiastic and skilful execution of the measuring programme at our laboratory.

\section{SUMMARY}

The effects of temperature on the initial mean velocity of cock spermatozoa and the rates of decrease of velocity and numbers of moving specimens in darkness and under a constant illumination have been studied, using a specially adapted standard egg-yolk - citrate diluent. Velocities and numbers of moving spermatozoa were determined with RIKMENSPOEL's (I957 $b$ ) photo-electric method, recalibrated for cock sperm.

The initial mean velocity increases non-linearly up to $45^{\circ} \mathrm{C}$ and falls down rapidly above $55^{\circ} \mathrm{C}$.

Over a range of storage temperatures of +0 up to $45^{\circ} \mathrm{C}$ the rate constants of decrease of velocity with time - $\partial v / \partial t$, of decrease of numbers of normally moving sperms $k_{\mathrm{N}}$ and of migration rates $k_{\mathbb{N}} \bar{v}$ were found to fit the Arrhenius equation for temperature dependence of the rate constants of chemical reactions, implying that linear relationships are obtained in this region by plotting log $(-\partial v / \partial t), \log k_{\mathrm{N}}$ or $\left.\log k_{\mathrm{N}} \bar{i}\right)$ as a function of $\mathrm{I} / \mathrm{T}(\mathrm{T}=$ absolute temperature). The apparent energies of activation of the deteriorating process came out to be $17088 \pm 1620 \mathrm{cal} / \mathrm{mole}$ for the samples kept in darkness, and $12200 \pm 2500 \mathrm{cal} /$ mole under a constant illumination of $983 \pm 3$ lux.

Photo-sensitivity of cock spermatozoa is lower than that of bull sperm. As in bull spermatozoa it is significantly correlated with temperature, also following the Arrhenius type of equation (Corr. $\log$ (photo-sensitivity) X $\mathrm{I} / \mathrm{T}: r=-0.98,0.001>\mathrm{P}$ ). This is explained by the light effect being a multiple-target process. The apparent energy of activation of the photochemical process was $-2534 \mathrm{cal} / \mathrm{mole}$ for cock spermatozoa, which is lower than has been found in previous investigations for those of the bull, being $-895^{8} \mathrm{cal} / \mathrm{mole}$. $Q_{10}$ values of photo-sen itivity of cock spermatozoa varied from $0.84-0.87$ over the range from $0-40^{\circ} \mathrm{C}$, showing that its temperature dependence is mainly due to the photochemical process itself and not to secondary thermal reactions.

\section{RÉFÉRENCES BIBLIOGRAPHIQUES}

DuIJN C., VAN Jr., I96r. Effects of light and optical sensitization by acridine-orange on living bull spermatozoa. Nalure, Lond., 189, 76.

DUIJN C. VAN, Jnr, I962. Velocity characteristics and numbers of bull spermatozoa in relation to ageing, determined by photo-electric methods. J. Reprod. Fertil., 4, 277 .

DUIJN C. VAN, I963. Bevruchtend vrrm gen van spe matozca in verband met hun beueeglijkheidsken merken en overlevingsduur. I. Kinetische theorie van de bevruchtingskans. Report Nr. B 48 of the Research Institute for Animal Husbandry' Schoonoord', Zeist, The Netherlands. 409 p.

DUIJN C. VAN, Jr., Lierop J. H. VAN, I966. Effects of temperature on photo-sensitivity of spermatozoa. Nature, Lond., 211, I 3.13.

Duijn C. VAN, Jr., Rikmenspoel R., I960. The mean velocity and velocity distributions of normal bull spermatozoa at different hydrogen ion concentrations, derived from photo-electric measurements. J.agric. Sci., 54, 300 . 
FAWCETT D. W., I962. Sperm tail structure in relation to the mechanism of movement. In : D. W. Bisuop (Ed.). Spermatozoan motility, 447 .

LAKE P. E., 1965, i966. Personal communications.

MEES C. E. K., 1954. The theory of the photographic process. MacMillan, New York.

Norman C., Goldberg E., I96r. The effect of visible light on spermatozoa. J. Reprod. Fertil., 2, 5I I.

Norman C., Goldberg E., Porterfield I. D., 1962. The effect of visible radiation on the functional life-span of mammalian and avian spermatozoa.' Exp. Cell. Res., 28, 69 .

Rikmenspoes. R., i957 a. An optically clear egg-yolk diluent for bull spermatozoa. Experientia, $13,124$.

RIKMENSPOEL R., I957 b. Photoelectric and cinematographic measurements of the " motility" of bull sperm cells. Thesis, Utrecht University. Drukkerij J. J. Smit, Utrecht, Netherlands.

RIKMENSPOEL R., I960. Measurements of the "motility" of bull sperm cells under various conditions. $J$. agric. Sci., 54, 39.

RIKMENSPOEL R., I962. Biophysical approaches to the measurement of sperm motility. In : D. W. BISHOP (Ed.). Spermatozoan motility, 31. 